\title{
Sewage sludge ash as resource for phosphorous and material for clay brick manufacturing
}

Ottosen, L.M.; Bertelsen, Ida M.G.; Jensen, Pernille E.; Kirkelund, Gunvor M.

Published in:

Proceedings ICSBM 2019

Publication date:

2019

Document Version

Publisher's PDF, also known as Version of record

Link back to DTU Orbit

Citation (APA):

Ottosen, L. M., Bertelsen, I. M. G., Jensen, P. E., \& Kirkelund, G. M. (2019). Sewage sludge ash as resource for phosphorous and material for clay brick manufacturing. In Proceedings ICSBM 2019: 2nd International Conference on Sustainable Building Materials (Vol. 4, pp. 119-130). [064]

\section{General rights}

Copyright and moral rights for the publications made accessible in the public portal are retained by the authors and/or other copyright owners and it is a condition of accessing publications that users recognise and abide by the legal requirements associated with these rights.

- Users may download and print one copy of any publication from the public portal for the purpose of private study or research.

- You may not further distribute the material or use it for any profit-making activity or commercial gain

- You may freely distribute the URL identifying the publication in the public portal 


\title{
Sewage sludge ash as resource for phosphorous and material for clay brick manufacturing
}

\author{
Lisbeth M. Ottosen ${ }^{1}$, Ida M.G. Bertelsen ${ }^{1}$, Pernille E. Jensen ${ }^{1} \&$ Gunvor M. Kirkelund ${ }^{1}$ \\ ${ }^{1}$ Department of Civil Engineering, Brovej, Building 118, Technical University of Denmark, 2800 Lyngby, \\ Denmark
}

\begin{abstract}
Sewage sludge ash (SSA) contains the critical raw material phosphorous. Internationally, research is carried out on utilization of SSA as secondary resource in concrete, bricks or lightweight aggregates; however, the high phosphorous content calls on recovery prior to such use. In the present investigation, phosphorous was recovered from SSA by electrodialytic separation (EDS) and the treated ash (SSA-EDS) was tested as clay substitute in brick manufacturing. For comparison, similar tests were conducted with SSA. The SSA had a reddish colour from a high iron oxide content. The SSA was milled to $\mathrm{d}_{50}=37 \mu \mathrm{m}$ prior to use as clay substitute (0-50\%). During EDS, 85-91\% phosphorous was recovered, the alkaline $\mathrm{pH}$ of the SSA (10.2) was reduced to acidic (3.7), and the content of iron oxides increased. The reference brick material was yellow. The colour turned increasingly reddish with increasing percentage of SSA and especially SSA-EDS, and the reddish colour is seen as an advance. The clay contained about $17 \%$ carbonates, a major cause for firing mass shrinkage. As the carbonate content decreased with increasing clay substitution, the shrinkage mass did decrease accordingly. When fired at $1000{ }^{\circ} \mathrm{C}$, all brick materials had apparent densities and open porosities within the range of bricks used in the building industry. SEM micrographs showed that mixes with SSA-EDS fired at $1050{ }^{\circ} \mathrm{C}$ contained a glassy phase with isolated spherical pores, which may be related to the high hematite content of SSA-EDS. The open porosity decreased with increasing substitution with SSA-EDS when fired at $1050{ }^{\circ} \mathrm{C}$, the reversed order compared to firing at $1000^{\circ} \mathrm{C}$.
\end{abstract}

Keywords: Brick manufacturing, sewage sludge ash, secondary resources, clay substitute, phosphorous

\section{Introduction}

Sewage sludge incineration is extensively practiced in European countries such as the Netherlands, Switzerland, and Germany. Sewage sludge ash (SSA) is unavoidably formed and research is carried out internationally in order to valorise this waste product. One research line is to utilize SSA in construction materials. Most research has been conducted on the use as partly cement replacement in concrete [1-3], as partly clay replacement in clay bricks [4-5], or by itself, where it is utilized that SSA itself can sinter and form new ceramic materials [7]. It is though important to recognise that SSA can be an important future secondary resource for phosphorous $(\mathrm{P})$, and that the $\mathrm{P}$ is lost for recovery if incorporated into construction materials. Recovery of $\mathrm{P}$ from secondary resources is important, since $\mathrm{P}$ is a finite, essential resource, underlined by $\mathrm{P}$ being in the list of critical raw materials for the EU [8]. The P concentration is generally high in SSA and can even be within the range of economical grade phosphate rock [9].

Different techniques are under development for P recovery from SSA. A group of techniques is based on wet extraction (mainly acid extraction). A major challenge with wet extraction is the simultaneous extraction 
of heavy metals and $\mathrm{P}$, which requires a second step after the extraction, where $\mathrm{P}$ and heavy metals are separated. We have developed and patented a technology, electrodialytic separation (EDS), which is a onestep process where P extraction and heavy metal separation occur simultaneously [10]. Recovery of 80$90 \%$ P from SSA and simultaneous separation of heavy metals has been obtained at laboratory scale. The produced P product has a low content of heavy metals corresponding to the very low end of commercial $\mathrm{P}$ fertilizers [9]. An SSA after EDS for P recovery (SSA-EDS) was previously seen to have potential as cement replacement in mortar [11]. At 20\% replacement, the compressive strength decreased with $8 \%$ (out of 60 $\mathrm{MPa}$ ), and the mortar got an intense red colour, however, the workability was decreased and work needs to be done to improve this property. In the present paper, SSA-EDS is investigated used as partly replacement for clay in clay bricks. Clay, which after firing, result in the traditional red coloured bricks is becoming scarce in Denmark, as deeper in the quarrels, the $\mathrm{Ca} / \mathrm{Fe}$ ratio determines the bricks to become yellow. In this investigation, it is suggested to use SSA both as replacement for the natural raw material (clay) with a secondary resource in brick manufacturing and as a colouring agent, which gives sought after red bricks. The aim is to investigate the properties of brick material with different replacement percentages of clay with SSA-ED (0-50\%) and investigate the colour potential. The work consists of two parts: (I) comparison of SSA and SSA-EDS as clay replacement material and (II) influence of firing temperature on the material properties when replacing clay with different percentages of SSA-EDS.

\section{Methodology}

\subsection{Materials}

SSA was collected at the wastewater treatment plant Avedøre Spildevandscenter BIOFOS in Copenhagen, Denmark (February 2015). The sewage sludge was incinerated in a fluidized bed combustor at about 850 ${ }^{\circ} \mathrm{C}$. The plant treats wastewater from 255.000 person equivalents (PE). Phosphorous is removed from the wastewater through chemical precipitation with $\mathrm{Fe}$, and due to the subsequent high content of iron-oxides, the SSA has the characteristic red colour. The SSA was sampled as a mix of electrofilter ash and bag filter ash $(2 \%)$. The SSA was collected directly from the process line and stored in sealed plastic containers at room temperature. As SSA and SSA-EDS are quite coarse-grained compared to clay [11], the SSA was milled in a vibrating cup mill (FRITSCH - pulverisette 9) for $10 \mathrm{sec}$ prior to being mixed into the clay in this investigation (Part I) or prior to EDS (Part II).

The clay used was from the brick manufacturer Wienerberger in Helsinge, Denmark. The clay was ready for use in the manufacturing of yellow clay bricks when sampled for this investigation.

\subsection{Characterization of SSA and clay}

Particle size distribution was measured using a Malvern Mastersizer 2000 with a dry SSA sample. The carbonate content of the clay was determined volumetrically by the Scheibler-method and calculated assuming that all carbonate present is calcium carbonate. The $\mathrm{pH}$ was measured in a suspension of 1:2 ash:distilled water after 1 hour of agitation. Loss on Ignition (LoI) was found after 30 minutes at $550^{\circ} \mathrm{C}$. Solubility in water was evaluated: $50.0 \mathrm{~g}$ ash suspended in $500 \mathrm{ml}$ distilled water and agitated for $1 \mathrm{~min}$. After settling, the water was decanted. New $500 \mathrm{ml}$ distilled water added. This was repeated so the ash was washed three times. Finally, the suspension was filtered and the ash dried at $105^{\circ} \mathrm{C}$ and weighed. The water solubility was measured in two replicates. The elemental concentrations of $\mathrm{Cd}, \mathrm{Cr}, \mathrm{Cu}, \mathrm{Zn}, \mathrm{P}, \mathrm{S}$ and $\mathrm{K}$ in SSA and SSA-DES were measured by ICP-OES after pre-treatment according to Danish standard (DS 259 2003), where $1.0 \mathrm{~g}$ of dry sample and $20.0 \mathrm{~mL} 7.3 \mathrm{M} \mathrm{HNO} 3$ were heated at $200 \mathrm{kPa}\left(120^{\circ} \mathrm{C}\right)$ for $30 \mathrm{~min}$. The liquid was separated from the solid particles by vacuum through a $0.45 \mu \mathrm{m}$ filter and diluted to $100 \mathrm{ml}$. 


\subsection{EDS of SSA for $P$ recovery}

The EDS for P recovery from SSA was conducted in a two compartment cell as described in [9] (figure 1). The SSA was suspended in distilled water in the anode compartment, and an electric current was applied to recover $\mathrm{P}$ and simultaneously remove heavy metals to have a clean $\mathrm{P}$ product. At the end of the treatment, the recovered $\mathrm{P}$ is in the filtrate of the anolyte and the solubilized heavy metals in the catholyte. Filtration separates SSA-EDS and the filtrate with the recovered P.

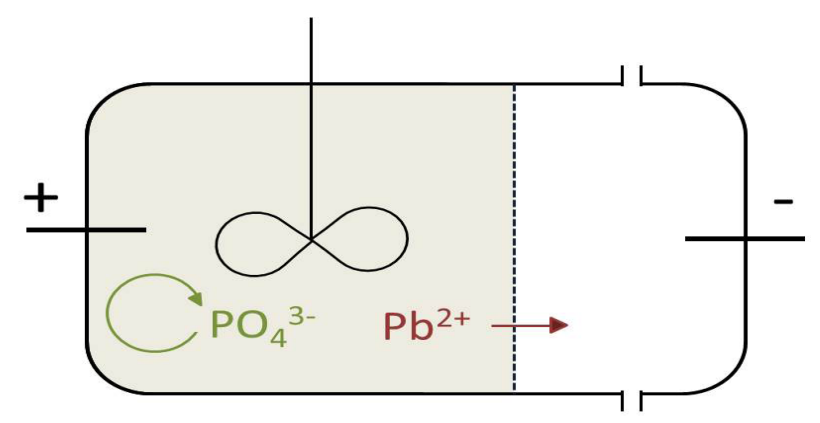

Figure 1: ED cell. The ash is suspended in water in the anode compartment and a cation exchange membrane (marked as dotted line) separates the two compartments.

The experiments were conducted in a cylindrical cell. The length of the anode compartment with SSA suspension was $10 \mathrm{~cm}$ and the length of the cathode compartment $5 \mathrm{~cm}$. The internal diameter of both compartments was $8 \mathrm{~cm}$. The cation exchange membrane was from Ionics. The platinum coated titanium wire electrodes (diameter $3 \mathrm{~mm}$ ) were obtained from Permascand $(\mathbb{R})$ and the length of the electrodes inside the cell was approximately $4 \mathrm{~cm}$. A power supply (Hewlett Packard E3612A) was used to maintain a constant current of $50 \mathrm{~mA}$. The specific parameters for the EDS process were chosen from the best results obtained in [9]: $25 \mathrm{~g} \mathrm{SSA}$ (milled for $10 \mathrm{sec}$.) was suspended in $350 \mathrm{ml}$ distilled water and $50 \mathrm{~mA}$ was applied for 6 days. The SSA was kept suspended by an overhead stirrer (RW11 basic from IKA). In the cathode compartment $500 \mathrm{~mL} 0.01 \mathrm{M} \mathrm{NaNO}_{3}$ adjusted to $\mathrm{pH} 2$ with $\mathrm{HNO}_{3}$ was circulated. During experiments, $\mathrm{pH}$ was adjusted manually in the cathode compartment to between 1 and 2 daily with $1 \mathrm{M} \mathrm{HNO}_{3}$. At the end of the EDS experiments, the suspension was filtered at atmospheric pressure and the SSA-EDS was dried at $105^{\circ} \mathrm{C}$. The $\mathrm{pH}$ and contents of $\mathrm{Cd}, \mathrm{Cr}, \mathrm{Cu}, \mathrm{Zn}, \mathrm{P}, \mathrm{S}$ and $\mathrm{K}$ were measured in the SSA-EDS.

To have sufficient SSA-EDS for production of brick discs, eight EDS experiments were conducted: 5 experiments for part (I) and 3 experiments for part (II). It was previously shown [9] that repeatability of EDS results with the same SSA is high, and thus SSA-EDS from all the experiments within each part of the investigation were mixed before analysing the chemical content of selected elements. The brick discs were produced with EDS-SSA from the mixed samples.

\subsection{Production and properties of brick discs}

Torres et al. (2009) [12] demonstrated that initial tests conducted on small-scale brick discs were a useful screening tool for selecting the best mixtures composition when incorporating wastes (from natural rock cutting and polishing) in clay to produce roof tiles. In this paper, a similar approach was adapted, using the same disc size as described by Torres et al. (2009) [12], however, it is SSA or SSA-EDS, treated SSA, which is mixed into the clay.

When mixing the clay material, $15 \mathrm{~g}$ dry blended clay and SSA/SSA-EDS was mixed with distilled water 
by hand until a uniform mass with a good workability was obtained. The mass of distilled water needed to obtain this state increased with increasing replacements. The liquid to solid $(\mathrm{L} / \mathrm{S})$ ratio in the reference mix was 0.25 , which was the lowest, and L/S was highest for the mixtures with $50 \%$ replacement with SSA and SSA-EDS (about 0.50). The mixes were stored overnight in sealed plastic beakers. Discs were produced from about $2.5 \mathrm{~g}$ of the mixes by uniaxial compression in a purpose built stainless steel die [13] placed in an Instron-6022. A load of $10 \mathrm{kN}$ (equivalent to the forming pressure of $31.8 \mathrm{MPa}$ ) was applied. During the compression, water was pressed out of the mixture. The green discs had a diameter of $2.0 \mathrm{~cm}$ and a height of $3.5-4 \mathrm{~mm}$. The weight of the unfired discs after compression $\left(\mathrm{m}_{0}\right)$ were measured. The discs were dried at $105^{\circ} \mathrm{C}$ for $24 \mathrm{~h}$ before the weights $\left(\mathrm{m}_{105^{\circ} \mathrm{C}}\right)$ were measured again. From these measurements, the water content of the unfired discs after the compression were calculated as $\left(\mathrm{m}_{0}-\mathrm{m}_{105^{\circ} \mathrm{C}}\right) / \mathrm{m}_{0}$. The discs were fired at 950,1000 or $1050^{\circ} \mathrm{C}$ for $2 \mathrm{~h}$ in a Nerbertherm laboratory furnace, using an average heating and cooling rate of $6.0^{\circ} \mathrm{C} / \mathrm{min}$.

Brick discs were prepared from different mixtures, see Table 1.

Table 1: Overview of the clay replacement percentage and firing temperature for the produced clay brick discs

\begin{tabular}{ccccc}
\hline & Replacement $(\mathrm{wt} \%)$ & $950^{\circ} \mathrm{C}$ & $1000^{\circ} \mathrm{C}$ & $1050^{\circ} \mathrm{C}$ \\
\hline Ref & 0 & $\mathrm{X}$ & $\mathrm{X}$ & $\mathrm{X}$ \\
& 10 & & $\mathrm{X}$ & \\
SSA & 30 & & $\mathrm{X}$ & \\
& 50 & $\mathrm{X}$ & $\mathrm{X}$ & $\mathrm{X}$ \\
& 10 & $\mathrm{X}$ & $\mathrm{X}$ & $\mathrm{X}$ \\
SSA-EDS & 30 & $\mathrm{X}$ & $\mathrm{X}$ & $\mathrm{X}$ \\
& 50 & & & \\
\hline
\end{tabular}

After cooling, the diameters were measured. Weights were measured as well, and the firing mass loss found:

Firing mass loss: $\left(\left(\mathrm{m}_{100^{\circ} \mathrm{C}}-\mathrm{m}_{1000^{\circ} \mathrm{C}}\right) / \mathrm{m}_{105^{\circ} \mathrm{C}}\right) * 100 \%$

The open porosity and density were determined. The discs were placed in a desiccator under vacuum for approximately $3 \mathrm{~h}$. After $3 \mathrm{~h}$, distilled water at room temperature was led into the desiccator, so that the discs were completely submerged. Vacuum was maintained for $1 \mathrm{~h}$ and hereafter, air was let into the desiccator and the submerged discs were left at atmospheric pressure overnight. The water-saturated discs were weighed in water $\left(\mathrm{m}_{\mathrm{sw}}\right)$ and in air after wiping excess water of the surface $\left(\mathrm{m}_{\mathrm{sa}}\right)$. The different properties were calculated as:

Volume $=\mathrm{V}=\left(\mathrm{m}_{\mathrm{sa}}-\mathrm{m}_{\mathrm{sw}}\right) / \varrho_{\mathrm{w}}$

Volume open pores $=\mathrm{V}_{\mathrm{op}}=\left(\mathrm{m}_{\mathrm{sa}}-\mathrm{m}_{1000{ }^{\circ} \mathrm{C}}\right) / \varrho_{\mathrm{w}}$

Dry mass density $=\mathrm{m}_{1000^{\circ} \mathrm{C} /}\left(\mathrm{V}-\mathrm{V}_{\mathrm{op}}\right.$

Open porosity $=\left(\left(\mathrm{m}_{\mathrm{sa}}-\mathrm{m}_{1000^{\circ} \mathrm{C}}\right) /\left(\mathrm{m}_{\mathrm{sa}}-\mathrm{m}_{\mathrm{sw}}\right)\right) * 100 \%$

Apparent density $=\left(\left(\mathrm{m}_{1000^{\circ} \mathrm{C}} * \varrho_{\mathrm{w}}\right) /\left(\mathrm{m}_{\mathrm{sa}}-\mathrm{m}_{\mathrm{sw}}\right)\right)$

Where $\varrho_{\mathrm{w}}\left(970 \mathrm{~kg} / \mathrm{m}^{3}\right)$ is the density of water at room temperature

The firing mass loss was measured in 7 replicates. Dry mass density, open porosity and apparent density in 
3 replicates.

\section{Results and discussion}

\subsection{Characterization of SSA (as received) and SSA-ED}

The carbonate content of the clay was $17.9 \pm 0.4 \%$. The grain size $d_{50}$ for the SSA as received was 120 $\mu \mathrm{m}$, and after milling, the $\mathrm{d}_{50}$ was decreased to $37 \mu \mathrm{m}$. The LoI of the SSA was very low $(0.3 \pm 0.005 \%)$ revealing a good incineration and following low mass loss from organic matter during firing of the brick discs. The water solubility was $1.4 \%$, representing soluble salts. Soluble salts in brickmaking raw materials is of concern for manufacturers as they can cause a production fault known as "drier scum" [14], however the problematic range and type of salts was not stated, and it is here considered that the content of soluble salts in the SSA is in an acceptable level.

The initial $25 \mathrm{~g}$ were reduced to $14-15 \mathrm{~g}$ during EDS, i.e. a mass reduction of $40 \%$. The dissolution was due to acidification of the SSA suspension from electrolysis at the anode. The $\mathrm{pH}$ of SSA was 10.2, and the $\mathrm{pH}$ of SSA-EDS was 3.7. Thus, the SSA was originally alkaline, while the ash became acidic after EDS. Table 2 shows the concentrations of selected heavy metals and macro elements in the SSA before and after EDS in the two parts of the experimental work. The heavy metal concentrations in SSA depend on the corresponding concentrations in the wastewater treated in the facility and do subsequently vary, however, the order in concentration reported (in $\mathrm{mg} / \mathrm{kg}$ ) is generally the same as here $\mathrm{Cd}<\mathrm{Cr}<\mathrm{Cu}<\mathrm{Zn}$ [3], [13], [14].

The concentrations of heavy metals and macro elements changed during EDS as seen in table 2. The removed percentage of all these elements was thus slightly higher in the EDS experiments in part (II) than in part (I), which corresponds well to the mass reduction of SSA, which was also slightly less in the part (I) experiments.

Table 2: $\mathrm{pH}$ and concentrations of selected elements in SSA and SSA-EDS in the two batches in part (I) and (II)

\begin{tabular}{cccccccc}
\hline & \multicolumn{4}{c}{ Concentration $(\mathrm{mg} / \mathrm{kg})$} & \multicolumn{3}{c}{ Concentration $(\mathrm{g} / \mathrm{kg})$} \\
\hline & $\mathrm{Cr}$ & $\mathrm{Cu}$ & $\mathrm{Cd}$ & $\mathrm{Zn}$ & $\mathrm{K}$ & $\mathrm{S}$ & $\mathrm{P}$ \\
\hline SSA & $40 \pm 0.1$ & $541 \pm 14$ & $2.2 \pm 0.03$ & $1986 \pm 56$ & $5.8 \pm 0.2$ & $6.1 \pm 0.1$ & $94.6 \pm 3.1$ \\
SSA-EDS (I) & $55 \pm 0.5$ & $395 \pm 7.9$ & $1.5 \pm 0.09$ & $1600 \pm 37$ & $3.7 \pm 0.08$ & $1.0 \pm 0.01$ & $25.4 \pm 0.7$ \\
SSA-EDS (II) & $45 \pm 0.9$ & $440 \pm 15$ & $0.8 \pm 0.1$ & $1890 \pm 60$ & $3.6 \pm 0.2$ & $0.6 \pm 0.02$ & $15.7 \pm 0.6$ \\
\hline
\end{tabular}

The $\mathrm{Cr}$ concentration increased during EDS, showing that $\mathrm{Cr}$ was bound mainly in the least soluble fraction of the SSA. The concentration of all other chemical elements in table 2 decreased. When taking into account the total mass reduction of $40 \%$ (part I) and 45\% (part II), the percentages of these chemical elements remaining in the SSA-EDS were:

$$
\begin{aligned}
& \text { Part (I): S }(10 \%)<\mathrm{P}(16 \%)<\mathrm{K}(38 \%)<\mathrm{Cd}(41 \%)<\mathrm{Cu}(44 \%)<\mathrm{Zn}(48 \%)<\mathrm{Cr}(83 \%) \\
& \text { Part (II): S }(6 \%)<\mathrm{P}(9 \%)<\mathrm{Cd}(19 \%)<\mathrm{K}(34 \%)<\mathrm{Cu}(44 \%)<\mathrm{Zn}(52 \%)<\mathrm{Cr}(62 \%)
\end{aligned}
$$

The P concentration in this batch of SSA is the same order (but in the lower end) of concentrations reported for SSA from other batches from the same plant: $90 \mathrm{~g} / \mathrm{kg}$ [3], $110 \mathrm{~g} / \mathrm{kg}$ [9] and [15] $123 \mathrm{~g} / \mathrm{kg}$. The economic grade of phosphate rock varies from $25 \%$ to $37 \% \mathrm{P}_{2} \mathrm{O}_{5}$ [16] corresponding to $110-160 \mathrm{~g} \mathrm{P} / \mathrm{kg}$ phosphate rock. Thus, the concentration in the SSA batch $94.6 \mathrm{~g} \mathrm{P} / \mathrm{kg}$ SSA was only slightly less than the mined natural ores. In the EDS experiments of the present investigation $91 \%$ and $84 \% \mathrm{P}$ was recovered in the experiments of part (I) and (II), respectively, which is in the same range as reported in [9], [17] in similar 
EDS experiments. Kappel et al (2018) [11] reported concentrations as oxides measured by XRF in SSA and SSA-EDS from the same incineration plant: the contents of $\mathrm{SiO}_{2}$ and $\mathrm{Fe}_{2} \mathrm{O}_{3}$ about doubled during EDS (from $18.6 \%$ to $39.4 \% \mathrm{SiO}_{2}$ and 15.75 to $27.3 \% \mathrm{Fe}_{2} \mathrm{O}_{3}$ ), while the content of $\mathrm{Al}_{2} \mathrm{O}_{3}$ was reduced slightly from 8.3 to $6.6 \%$. Similar concentration ranges are expected in the SSA and SSA-EDS of the present investigation.

On the basis of the XRD analysis, Kappel et al (2018) [11] identified of the minerals quartz, feldspar and hematite in SSA and SSA-EDS. Cheeseman et al (2003) [7] reported quarts, whitlockite (calcium magnesium phosphate mineral) and some hematite in an SSA from UK, and Anderson (2002) [18] quartz, calcite, hematite, anhydride, feldspar and glassy phase $\sim 70 \%$ in another SSA from UK. Thus, quartz and hematite were identified in all three ashes. The high concentration of hematite is due to the use of iron salts to precipitate $\mathrm{P}$ in the wastewater treatment facility. Other facilities use mainly $\mathrm{Al}$ salts and this strongly influences the chemical properties of the SSA [10], [19]. Thus, caution must be taken when generalizing results on utilization SSA in brick production, as the characteristics in the SSA varies, which must be expected to influence the brick quality. Significant changes in specifications carries a potential risk for production problems during brick manufacturing [14]. Thus, attention must be given to the characteristics of the specific SSA, when evaluating how and if it is best utilized in brick manufacturing.

\subsection{Properties of brick discs}

\subsubsection{Colour of brick discs}

The original yellow colour of the reference discs changed towards more red colours with increasing replacement of clay with SSA and SSA-ED, see figure 2. The red colour was more intense for the brick discs with SSA-EDS than for the corresponding discs with SSA, most clearly seen for $30 \%$ replacement. It is the higher content of iron oxides in SSA-EDS, which give this difference. The discs fired at $1050{ }^{\circ} \mathrm{C}$ and at replacements of $30 \%$ and $50 \%$ clay with SSA-EDS were significantly darker than the discs with same replacement but lower firing temperature. The red colour obtained at $30 \%$ replacement and $1000{ }^{\circ} \mathrm{C}$ was similar to traditional Danish red bricks.

\subsubsection{Water content of discs after pressing}

The water content of the green discs after pressing and before firing is ahown in table 3. There is no significant difference in water content between the discs with SSA and SSA-EDS within each substitution percentage when considering the standard deviations. The water content increased with increasing substitution with SSA or SSA-EDS. The SSA particles are porous [10], [14] and thus they can absorb water, which will increase the overall water content.

Table 3: Water content of unfired discs after pressing

\begin{tabular}{ccccc}
\hline & Ref & $10 \%$ & $30 \%$ & $50 \%$ \\
\hline SSA & & $10.2 \pm 0.5$ & $14.6 \pm 3.1$ & $15.2 \pm 0.7$ \\
SSA-EDS (I) & $9.4 \pm 0.6$ & $10.3 \pm 0.6$ & $12.6 \pm 1.2$ & $16.2 \pm 1.7$ \\
SSA-EDS (II) & $9.8 \pm 0.9$ & $10.6 \pm 0.6$ & $13.6 \pm 0.5$ & $16.8 \pm 0.8$ \\
\hline
\end{tabular}

\subsubsection{Comparison of brick discs with SSA and SSA-EDS}

The firing mass loss decreases with increasing percentages of SSA and SSA-EDS mixed into the clay (figure 3). The decreasing firing mass loss with increasing clay replacement with SSA is in consistency with what was reported by [4]. Firing mass loss can be due to removal of chemically bound water and volatilization of compounds within the brick [4]. The decomposition of $\mathrm{CaCO}_{3}$ in the clay is a major contributor to the 
ICSBM 2019

$2^{\text {nd }}$ International Conference of Sustainable Building Materials

shrinkage mass decrease. At increasing clay substitutions with SSA and SSA-EDS, the $\mathrm{CaCO}_{3}$ content in the mix decreases, and following the shrinkage mass.

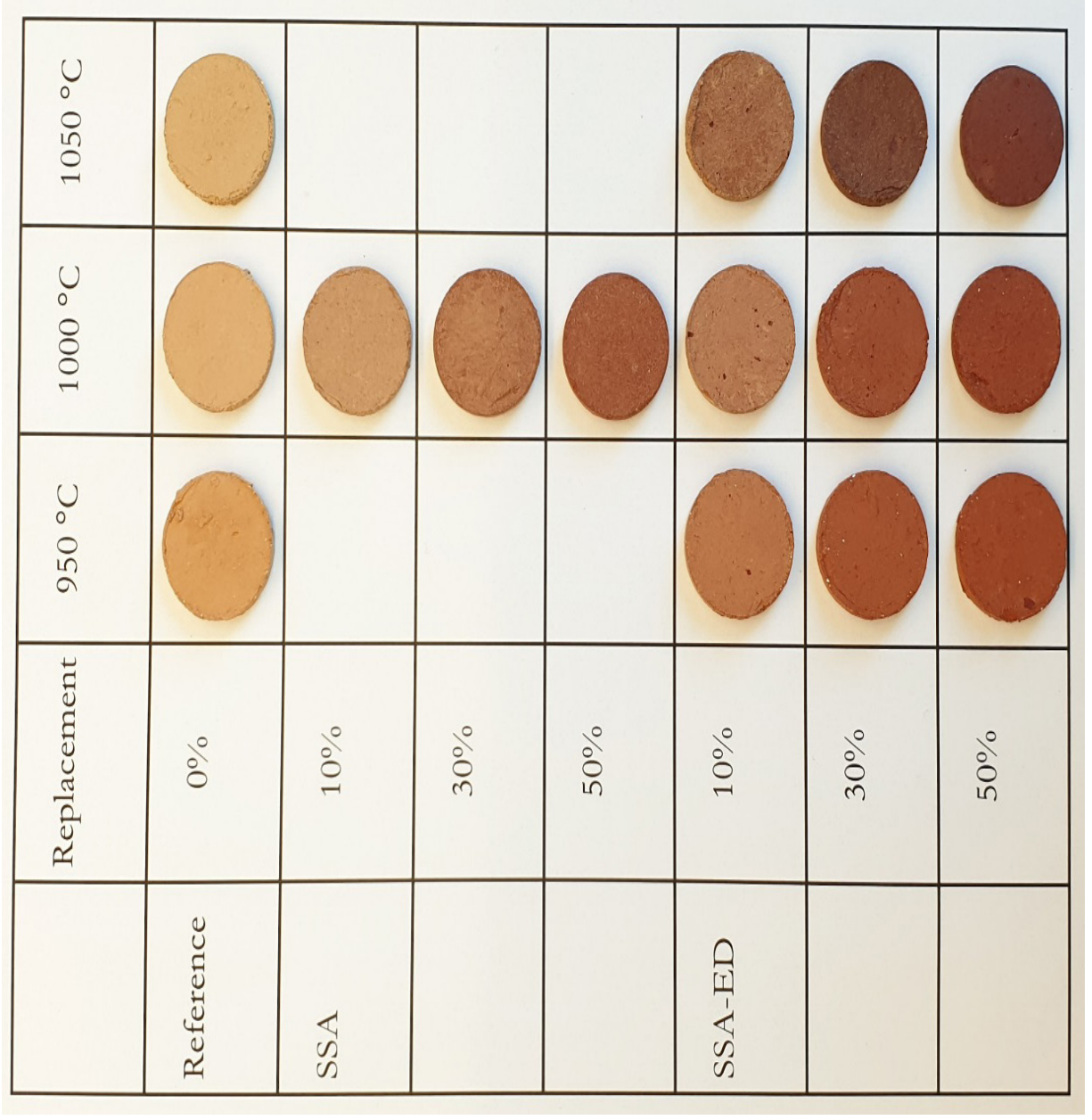

Figure 2: Colours of the brick discs in the investigation

The shrinkage mass decreases linearly with the clay substitution from $0-50 \%$ with SSA $\left(\mathrm{R}^{2}=0,9995\right)$ and from $10-50 \%$ replacement with SSA-EDX $\left(\left(\mathrm{R}^{2}=0,9996\right)\right.$, (figure 4). The linear relation between shrinkage mass and percentage of clay substitution with SSA-EDS does not include the reference. This is likely due to the acidic nature of SSA-EDX, which dissolves a small fraction of the carbonates in the clay when mixing. Thus, the carbonate content in the reference discs is higher than the background of carbonates in the discs with SSA-EDS. In addition, the carbonate content decreases relatively more with increasing percentage of SSA-EDX and thus the gradient differs from the one for SSA. The firing mass loss is smaller for the discs with SSA than for those with SSA-EDS even though the carbonate content is considered slightly higher in the discs with SSA. This indicates that there are phases contributing to the firing mass loss, which concentrate in the ash during EDS. Hematite can dissociate and form gas at temperatures as low as 1000 ${ }^{\circ} \mathrm{C}$ [20], and the higher hematite concentration in SSA-EDS than in SSA can be contributing to the higher firing mass loss for discs with SSA-EDS. 
ICSBM 2019

$2^{\text {nd }}$ International Conference of Sustainable Building Materials



Figure 3: Firing mass loss as function of replacement percentage

Figure 4 shows the apparent density, density of the solid mass and open porosity the discs in Part (I), all fired at $1000{ }^{\circ} \mathrm{C}$. The apparent density decreases, whereas the density of the solid mass and the porosity increases with increasing replacement of clay with SSA and SSA-EDS.

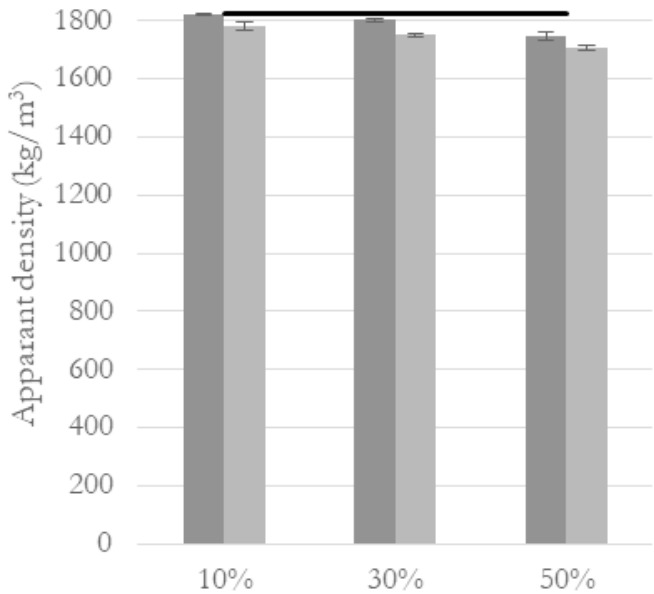$$
35
$$

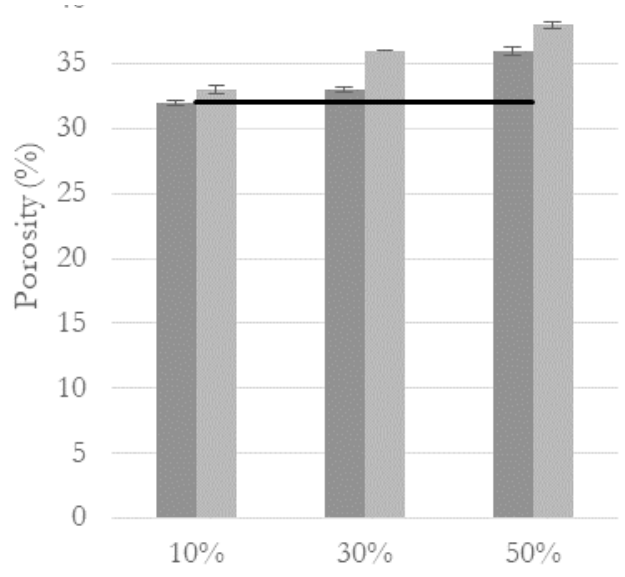

SSA SSA-EDS $100 \%$ Clat

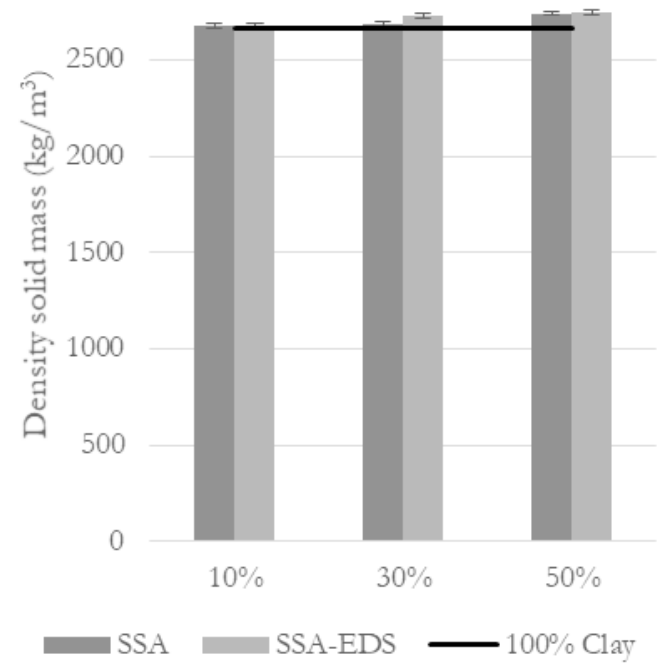

$\square$ SSA $\quad$ SSA-EDS $-100 \%$ Clay

Figure 4: Properties of brick discs fired at $1000^{\circ} \mathrm{C}$ with SSA or SSA-ED: (a) apparent density, (b) density of the solid mass, and (c) open porosity. 
The discs with SSA had higher apparent density and lower porosity than the discs with SSA-EDR. The decrease in apparent density is in consistency of what was reported by [4]. Apparent densities of clay bricks, which are used in the building industry, are in the range of $1610-2120 \mathrm{~kg} / \mathrm{m}^{3}$ [21] and open porosities in the range of 19-39 vol\% [21]. Both apparent density and porosity of all the brick discs in figure 4 are within these ranges, though the parameters are close to the upper and lower limit, respectively, in regards to the discs with 50\% SSA-EDS. This is encouraging; however, it must be taken into consideration that this result cannot be transferred directly to the manufacturing of bricks for the building industry, as the manufacturing of the small brick discs differs from the procedures at brickworks.

Summing up, the properties of the brick discs are different when SSA-EDS is used as clay substitute instead of SSA. The firing shrinkage mass decreases, whereas the open porosity apparent density and dry mass density increases. Of major importance to the differences are probably the acidic nature of SSA-EDS and the increased hematite content. In accordance to the properties included in this investigation, all the brick discs have properties as brick used in the building industry.

\subsubsection{Properties of brick discs with SSA-ESD fired at different temperatures}

Figure 5 shows the firing shrinkage at $950^{\circ} \mathrm{C}, 1000^{\circ} \mathrm{C}$ and $1050^{\circ} \mathrm{C}$ for the different clay/SSA-EDS mixes in part (II) of the investigation. The differences in firing shrinkage between the three temperatures within each substitution percentages are very small. On the contrary, the firing shrinkage is highly dependent on the replacement percentage. The more SSA-EDS, the lower firing shrinkage, which is likely due to the decreasing content of $\mathrm{CaCO}_{3}$ as discussed in paragraph 3.2.3.

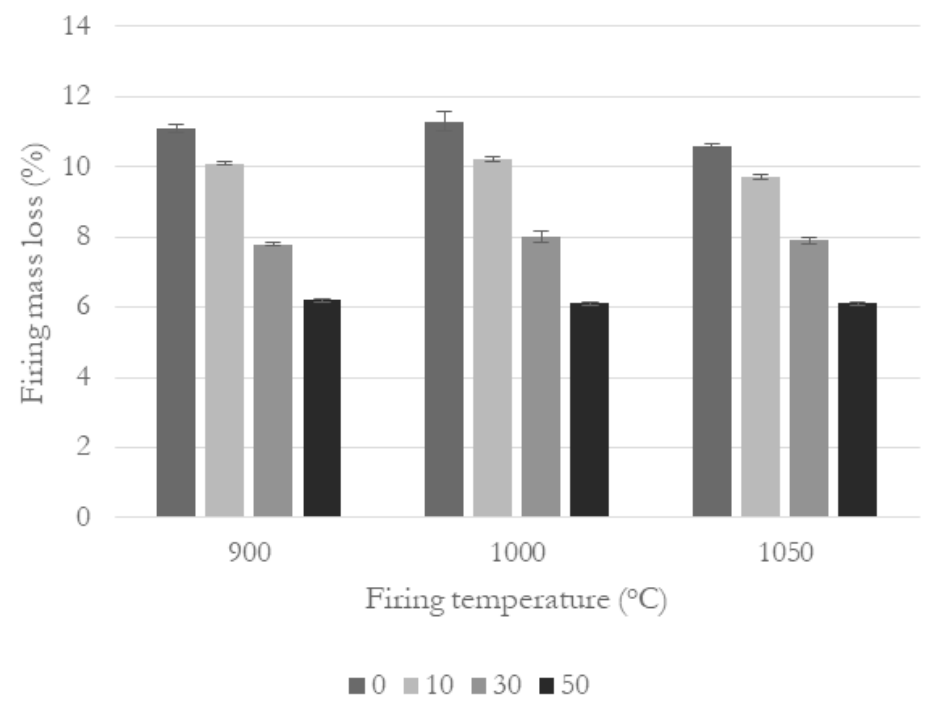

Figure 5: Firing shrinkage for brick discs with different replacements of clay with SSA-EDS and different temperatures.

The open porosity of the discs with SSA-EDS is seen in figure 6. It is evident that the porosity is highly influenced by the firing temperature between 1000 and $1050^{\circ} \mathrm{C}$. Until $1000^{\circ} \mathrm{C}$ the porosity slightly increases with increasing clay replacement and at $1050^{\circ} \mathrm{C}$ the order is reversed causing a significant decrease in open porosity. A similar finding was reported by [4], who reported that the cold water absorption for bricks with clay/SSA mixes had increasing water absorption with SSA content when fired at $1040^{\circ} \mathrm{C}$ and the order was reversed at $1120{ }^{\circ} \mathrm{C}$. The shift was thus found to be between $1000{ }^{\circ} \mathrm{C}$ and $1050{ }^{\circ} \mathrm{C}$ in the present investigation and between $1040{ }^{\circ} \mathrm{C}$ and $1120^{\circ} \mathrm{C}$ for another SSA by [4], i.e. the general temperature for the shift may be in the range of $1040{ }^{\circ} \mathrm{C}$ and $1050{ }^{\circ} \mathrm{C}$. The open porosity for the discs with 30 and $50 \%$ clay 
ICSBM 2019

$2^{\text {nd }}$ International Conference of Sustainable Building Materials

substitution with SSA-EDS (12.5\% and 23.6\%) is lower than the range of $19-39$ vol $\%$ stated for bricks used in the building industry by [21]. The firing temperature of $1050{ }^{\circ} \mathrm{C}$ must be considered too high for firing clay bricks with 30-50 \% replacements with SSA-EDS.

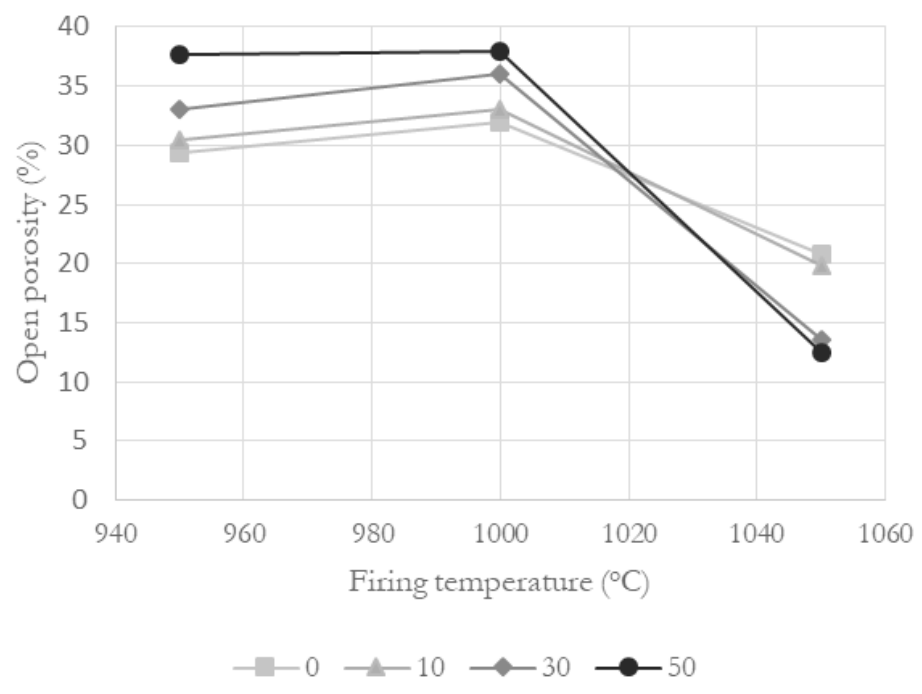

Figure 6: Open porosity of brick discs with different replacement percentages of clay with SSAEDS and different temperatures.

Figure 7 shows SEM micrographs of a fracture surface of a reference disc and a disc with $50 \%$ clay replaced with SSA-EDS, both fired at $1050{ }^{\circ} \mathrm{C}$. The disc with SSA-EDS had a glassy-like phase, which was not seen in the reference disc (figure $7 \mathrm{a}$ and $7 \mathrm{~b}$ ). This is in accordance to Anderson (2002) [18], who also saw a glassy phase when firing clay and SSA at $1050{ }^{\circ} \mathrm{C}$. This indicates that EDS did not remove the compounds present in SSA involved in this vitrification. The glassy-like phase in the disc with SSA-EDS had isolated pores of about 5-15 $\mu \mathrm{m}$ with an almost spherical shape (figures $7 \mathrm{~b}$ and $7 \mathrm{~d}$ ). The same pattern with a sintered phase and isolated pores was not seen in the reference disc. Cheeseman et al. (2003) [7] studied sintering of $100 \%$ SSA and found that at $1040{ }^{\circ} \mathrm{C}$, a relatively low-density material, which appeared to be hard and well sintered with a glassy surface. A SEM micrograph of the fracture surface showed that the matrix contained a significant volume of isolated, approximately spherical pores, typically $20-30 \mu \mathrm{m}$ [7]. This finding is similar to the one in the present investigation. The isolated, spherical pores are likely formed by bloating, which is the phenomenon utilized in the production of lightweight aggregates. Two conditions necessary for bloating, which have long been recognized are (1) that a material must produce a high temperature glassy phase with a viscosity high enough to trap a gas and (2) that some substance must be present that will liberate a gas at a temperature at which a glassy phase has formed [20]. Riley (1951) [20] found that pyrite, hematite and dolomite provide the constituents necessary to cause gas evolution at a temperature high enough $\left(>1000^{\circ} \mathrm{C}\right)$ for the bloating to take place. As hematite is a major mineral in SSAEDS [11], it is likely that hematite took part in the bloating of the sintered phase seen in figure $7 \mathrm{~b}$ and $7 \mathrm{~d}$. 


\section{ICSBM 2019}

$2^{\text {nd }}$ International Conference of Sustainable Building Materials
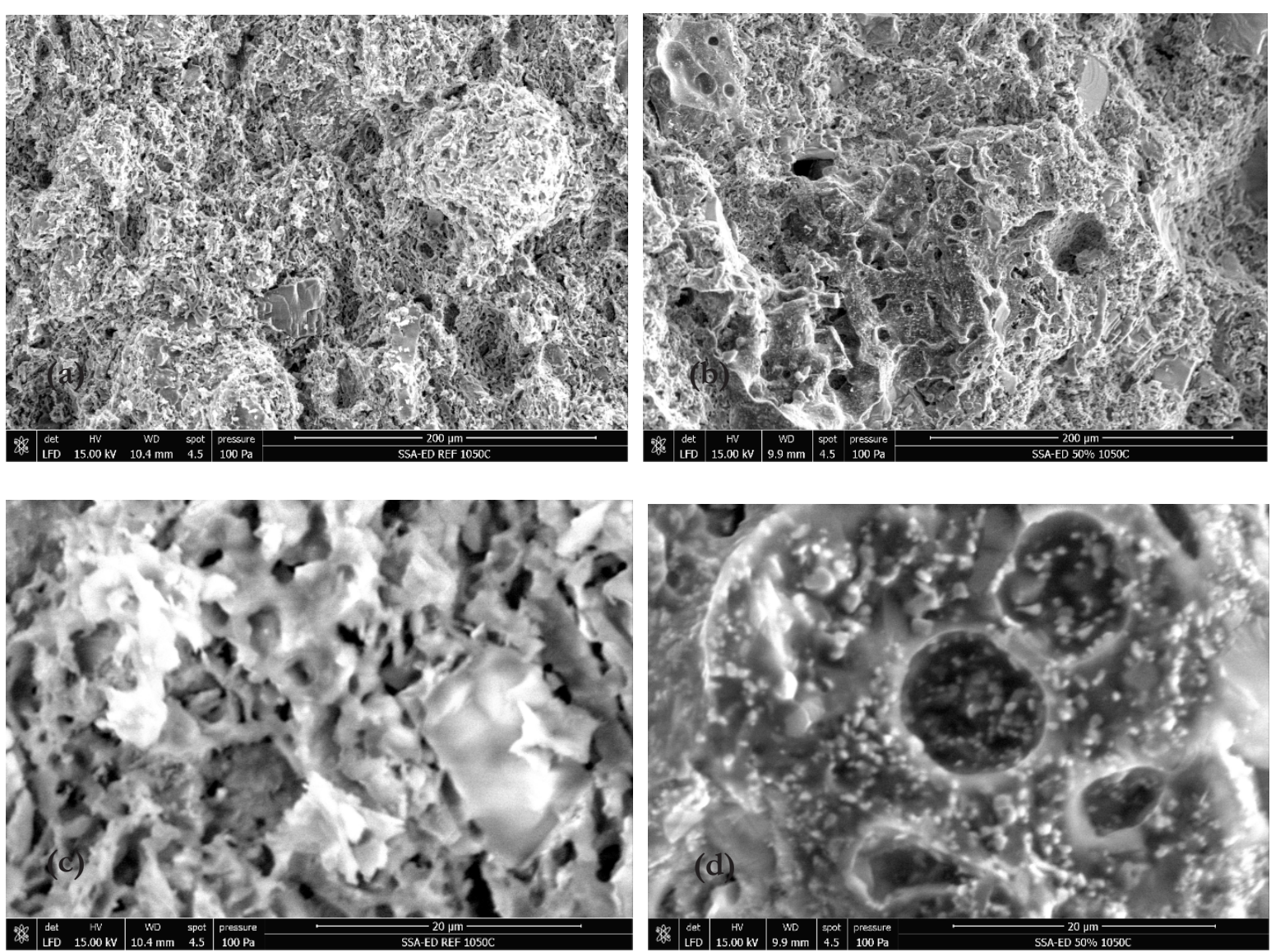

Figure 7: Fracture-face of morphology of discs fired at $1050{ }^{\circ} \mathrm{C}$ (a) reference disc and (b) disc with $50 \%$ SSA substituting clay (Same magnification), and high magnification (c) reference disc and (d) disc with $50 \%$ clay substitution with SSA (see scale at the lower bars the SEM micrographs).

Anderson (2002) [18] also reported formation of a glass phase when firing a clay/SSA mixture (5\% SSA) at $1050-1070{ }^{\circ} \mathrm{C}$ and a decrease in porosity (measured as water absorption). As the glassy phase develops, it draws the particles closer together, thereby reducing the internal packing voids thus making the product les porous [18]. This explanation may be underlined in the present investigation by the decreased diameter for the discs with $30 \%$ and $50 \%$ SSA-EDS fired at $1050{ }^{\circ} \mathrm{C}$, which were about 0.4 and $0.8 \mathrm{~mm}$ (out of the $20 \mathrm{~mm})$, respectively. All other discs kept the initial diameter $( \pm 0.2 \mathrm{~mm})$ after firing.

Very small particles $(<2 \mu \mathrm{m})$ were caught in the sintered phase (figure $3 \mathrm{~d}$ ). Whether these particles are crystalline or amorphous was not determined. They might be crystalline since Cheeseman et al. (2003) [7] reported that sintering of $100 \%$ SSA indicated that no significant crystalline transformations occurred during sintering and that the original crystalline phases quartz, calcium magnesium phosphate and some hematite was identified by XRD both before and after firing at $1040{ }^{\circ} \mathrm{C}$.

\section{Conclusions}

Electrodialytic separation (EDS) for recovery of phosphorous from sewage sludge ash (SSA) changes the overall composition of the ash. When used as clay substitution in brick making, major important changes in SSA characteristics were seen from EDS. Of major importance is considered, that the hematite concentration increases during EDS reaching levels of about $25 \mathrm{wt} \%$. The hematite content gave a reddish coloured brick material (the reference material from firing clay was yellow), and the colour change was most intense for SSA-EDS. The hematite also caused formation of a glassy-like phase with closed, spherical 
pores when discs were fired at $1050{ }^{\circ} \mathrm{C}$. This glassy-like phase strongly influenced the open porosity of the material. When fired at $1000^{\circ} \mathrm{C}$, the open porosity slightly increased with increasing clay substitution with SSA-EDS, whereas at $1050{ }^{\circ} \mathrm{C}$, the order was reversed, and the open porosity decreased significantly with increasing SSA-EDS content. The overall open porosity of the brick material decreased to 12.5 and $13.6 \%$, when 30 and 50\% clay was replaced with SSA-EDS and the mix was fired at $1050{ }^{\circ} \mathrm{C}$. These porosities are low and outside the levels of generally used bricks. When fired at $1000{ }^{\circ} \mathrm{C}$, the same mixes gave open porosities within the general range. From this investigation, it can be concluded that SSA-EDS can potentially be used in brick manufacturing similarly to SSA, however, attention must be given to the firing temperature at higher substitutions due to the increased content of hematite, which here strongly influences the brick properties.

\section{References}

[1] Donatello, S.; Cheeseman, C.R. (2013) Recycling and recovery routes for incinerated sewage sludge ash (ISSA): a review, Waste Management 33(11), 2328-2340

[2] Lynn, C.J.; Dhir, R.K.; Ghataora, G.S.; West, R.P. (2015) Sewage sludge ash characteristics and potential for use in concrete, Construction \& Building Materials 98, 767-779

[3] Kappel, A.; Ottosen, L.M., Kirkelund, G.M. (2017) Colour, compressive strength and workability of mortars with an iron rich sewage sludge ash. Construction \& Building Materials, 157, 1199-1205

[4] Trauner, E.J. (1993) Sludge ash bricks fired to above and below ash-vitrification temperature. J. Environ. Eng. 119(3), 506-519

[5] Lin, DF; Weng, CH (2001) Use of sewage sludge ash as brick material. Journal of Environmental Engineering 127(10), 922-927

[6] Suzuki, S.; Tanaka, M.; Kaneko, T. (1997) Glass-ceramic from sewage sludge ash. Journal of Materials Science 32(7), 1775-1779

[7] Cheeseman, C.R.; Sollars, C.J.; McEntee, S. (2003) Properties, microstructure and leaching of sintered sewage sludge ash. Resources, Conservation and Recycling 40, 13-25

[8] COM (2017) 490 On the 2017 list of Critical Raw Materials for the EU

[9] Ottosen, L. M.; Jensen, P.E.; Kirkelund, G.M (2016) Phosphorous recovery from sewage sludge ash suspended in water in a two-compartment electrodialytic cell. Waste Management 51, 142-148

[10] Ottosen, L.M.; Kirkelund, G.M.; Jensen, P.E. (2013) Extracting phosphorous from incinerated sewage sludge ash rich in iron or aluminum. Chemosphere, 91(7), 963-969

[11] Kappel, A.; Viader, R.P.; Kowalski, K.P.; Kirkelund, G.M.; Ottosen, L.M. (2018) Utilization of electrodialytically treated sewage sludge ash in mortar. Waste and Biomass Valorization, 9(12), 2503-2515

[12] Torres P., Fernandes H.R., Olhero S., Ferreira J.M.F. (2009) Incorporation of wastes from granite rock cutting and polishing industries to produce roof tiles. J Eur Ceram Soc 29, 23-30

[13] Chen, W.; Ottosen, L.M.; Jensen, P.E.; Kirkelund, G.M.; Schmidt, J.W. (2014) A comparative study on electrodialytically treated bio-ash and MSWI APC-residue for use in bricks. Proceedings of the 5th International Conference on Engineering for Waste and Biomass Valorization (WasteEng2014) Rio de Janeiro (ISBN: 979-10-91526-03-6), 648-662

[14] Anderson, M.; Skerratt, R.G. (2003) Variability study of incinerated sewage sludge ash in relation to 